\title{
Study on the effects of the different polar group of EPA-enriched phospholipids on the proliferation and apoptosis in 95D cells
}

\author{
Yao Guo ${ }^{1} \cdot$ Qin Zhao ${ }^{2} \cdot$ Yingying Tian $^{3} \cdot$ Yuanyuan Liu ${ }^{1} \cdot$ Ziyi Yan $^{1} \cdot$ Changhu Xue ${ }^{1,4} \cdot$ Jingfeng Wang ${ }^{1}$
}

Received: 13 July 2020 / Accepted: 2 February 2021 / Published online: 7 June 2021

(c) The Author(s) 2021

\begin{abstract}
EPA-enriched phosphatidylcholine (EPA-PC) and EPA-enriched phosphatidylethanolamine (EPA-PE) are newly identified marine phospholipids. The polar group of phospholipids is known to influence EPA-phospholipid activity. However, the differences in anti-tumor effects between EPA-PC and EPA-PE have not been reported. In this study, we evaluated the effects of two forms of EPA on the proliferation and apoptosis in the lung-cancer cell line 95D as well as possible molecular mechanisms. Our results showed that EPA-PC effectively inhibited proliferative activity and promoted apoptosis of 95D cells in a dose-dependent manner, while EPA-PE had no effect on cell proliferation, although it slightly promoted apoptosis. Western blot results showed that EPA-PC and EPA-PE upregulated the expression of PPAR $\gamma, \mathrm{RXR} \alpha$, and PTEN, and downregulated the PI3K/AKT signaling pathway. Furthermore, EPA-PC and EPA-PE induced the expression of the pro-apoptotic gene, Bax, and reduced the expression of the anti-apoptotic gene, Bcl-xl. Additionally, EPA-PC and EPA-PE promoted the release of cytochrome $c$ and activated the apoptotic enzyme-cleaved caspase-3. These data suggest that the anti-tumor effect of EPAphospholipids may be exerted via a PPAR $\gamma$-related mechanism. EPA-PC was more efficacious as compared to EPA-PE, which might be due to the different polar groups of phospholipids.
\end{abstract}

Keywords Marine phospholipid $\cdot$ EPA-PC $\cdot$ EPA-PE $\cdot$ Proliferation $\cdot$ Apoptosis $\cdot$ Lung cancer

\section{Introduction}

Cancer is the leading causing of death in over 91 countries. Worldwide, in 2018, approximately 18.1 million people were newly diagnosed and 9.6 million died (Nasim et al. 2018). Although scientists have made advancements in cancer treatment strategies, many cancers are still insurmountable

Edited by Xin Yu.

Yao Guo and Qin Zhao contributed equally to this work.

Jingfeng Wang

jfwang@ ouc.edu.cn

1 College of Food Science and Engineering, Ocean University of China, Qingdao 266003, China

2 School of Food Engineering, Ludong University, Yantai 264025, China

3 Marine Biomedical Research Institute of Qingdao, Qingdao 266061, China

4 Laboratory for Marine Drugs and Bioproducts, Pilot National Laboratory for Marine Science and Technology (Qingdao), Qingdao 266237, China and present with poor prognosis and high mortality (Petpiroon et al. 2019). More importantly, reduced sensitivity to radiotherapy and chemotherapy and a high probability of recurrence and metastasis are also critical issues (Shen et al. 2019). Nutritional intervention adjuvant therapy is gaining popularity in cancer treatment. Abdi et al. (2014) found that omega- 3 fatty acids could enhance the sensitivity of multiple myeloma cells to the anti-tumor drug, bortezomib.

The peroxisome-proliferation-activated receptor gamma $(\operatorname{PPAR} \gamma)$ is a member of the nuclear receptor family and a key transcriptional regulator of fatty acid and glucose metabolism (Sascha 2015). Recently, substantial evidence indicates that PPAR $\gamma$ has the characteristics of a tumor suppressor. PPAR $\gamma$ is expressed in many cancers including those of the colon, breast, and prostate, and PPAR $\gamma$ ligands are generally found to have anti-proliferative effects in these cells (Lehrke et al. 2005). The loss of PPAR $\gamma$ may create a pro-tumorigenic microenvironment (Apostoli et al. 2013). Studies have shown that PPAR $\gamma$ agonists can inhibit the growth of a variety of cancer cells in vitro, and in combination with other chemotherapeutic drugs, can enhance the anti-tumor effect of the drugs. This effect could be reversed 
by the PPAR $\gamma$ inhibitor, GW9662 (Jiang et al. 2015; Skelhorne-Gross et al. 2012).

Eicosapentaenoic acid (EPA) is an omega-3 longchained polyunsaturated fatty acid that exerts many physiological effects (Acharya et al. 2019; Bonnet and Ferrari 2011; Peng et al. 2020; Soni et al. 2019). For example, a large number of studies have reported its anti-tumor effect. Study authors reported that EPA could inhibit proliferation, promote apoptosis and autophagy of cancer cells (Zhang et al. 2007; Zheng et al. 2017), and effectively inhibit the growth and metastasis of tumors (Eltweri et al. 2016). In recent years, EPA has been proven to be a natural ligand for PPAR $\gamma$ (Lehrke et al. 2005), which may explain its anti-tumor effect. EPA-enriched phospholipids (PLs) are newly discovered marine phospholipids that contain
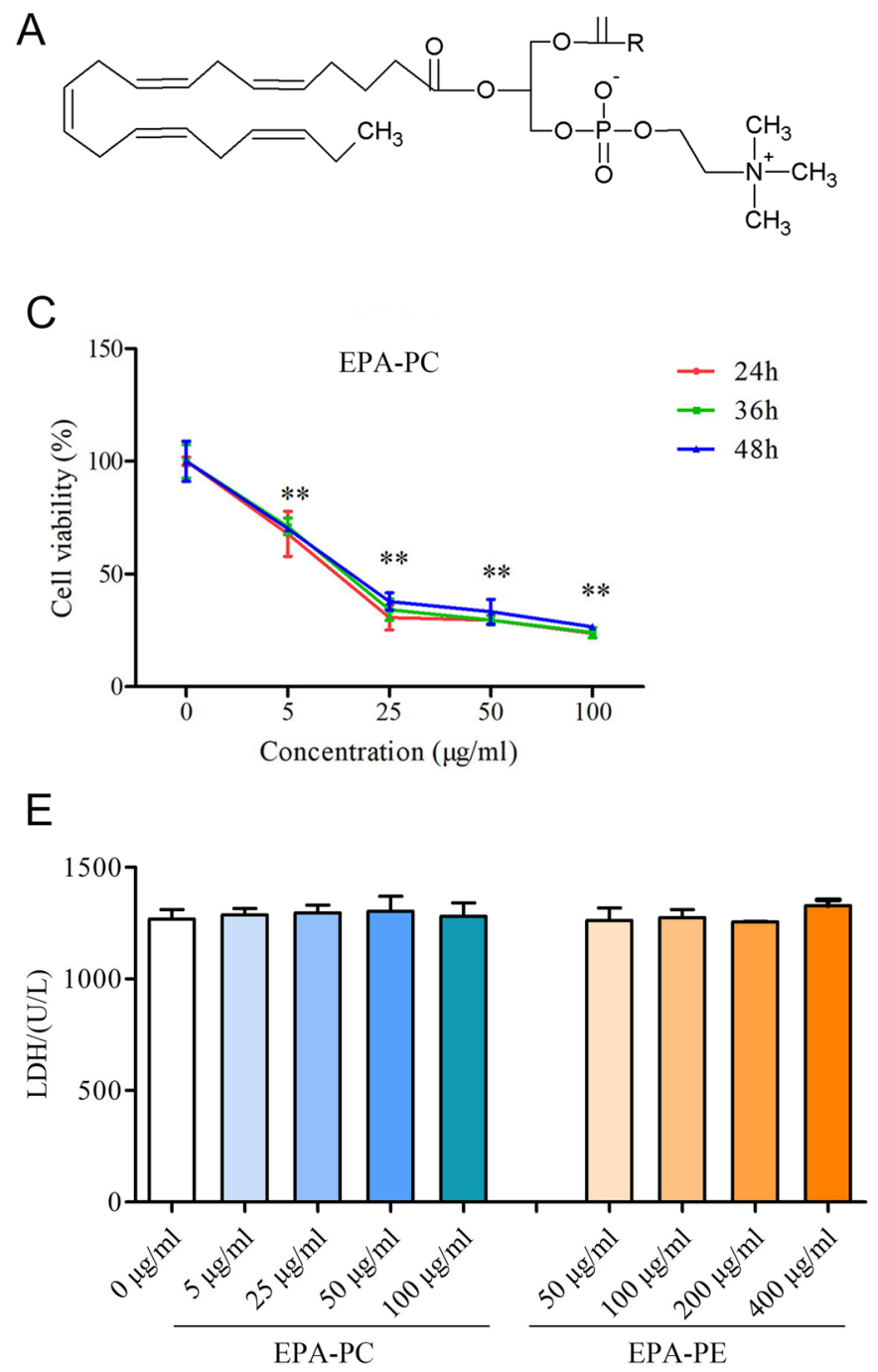

Fig. 1 Effect of EPA-PC and EPA-PE on the growth of 95D lungcancer cells. a The general structure of EPA-PC. b The general structure of EPA-PE. c 95D cells were treated with different concentrations of EPA-PC for 24, 36, and 48 h. d 95D cells were treated with abundant EPA in the sn-2 position of the carbon skeleton. Examples of this class of compounds include EPAenriched phosphatidylcholine (EPA-PC), EPA-enriched phosphatidylethanolamine (EPA-PE), and EPA-enriched phosphatidylserine (EPA-PS). The general structures of EPA-PC and EPA-PE are shown in Fig. 1a, b. The different polar groups at the sn-3 position of the phospholipid glyceryl group are responsible for differences in nutritional properties among these compounds. Zhou et al. (2018a, b) reported that EPA-PS shows better improvement effects than EPA-PC/PE on neurotrophic activity. They also point out that these effects might be attributed to the polar phospholipid groups. Data on the bioavailability and biological effects of different forms of EPA can help people choose more nutritional foods to obtain necessary fatty acids.<smiles>[R]OCC(COP(=O)([O-])OCCN)OC(=O)CCC/C=C\C/C=C\C/C=C\C/C=C\C/C=C\C</smiles>

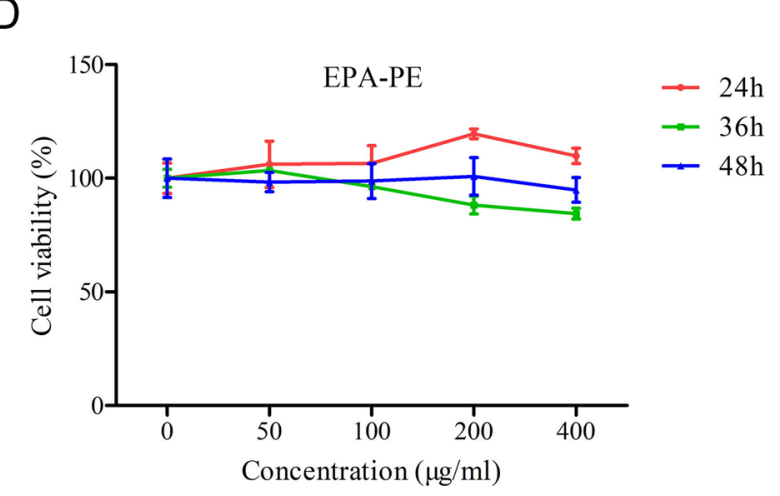

different concentrations of EPA-PE for 24, 36, and $48 \mathrm{~h}$. Cell viability was determined by MTT assay. e Effects of EPA-PC and EPA-PE on LDH activity in supernatant. $* * P<0.01$ versus control group. The data are presented as the mean $\pm \mathrm{SD}$ of three separate experiments 
However, there are no studies comparing the anti-tumor activity of EPA-PC and EPA-PE.

In the present study, we compared the effects of different forms of EPA on the proliferation and apoptosis of 95D lung-cancer cells. We also studied their molecular mechanisms in vitro to provide theoretical support for nutritional adjuvant therapy for cancer and for the high-value utilization of sea cucumbers.

\section{Results}

\section{Effect of EPA-PC and EPA-PE on the proliferation of 95D cells}

We first examined the effects of EPA-PC and EPA-PE on the proliferation of 95D cells. As shown in Fig. 1c, EPA-PC significantly inhibited the growth of 95D cells in a dosedependent manner. The $\mathrm{IC}_{50}$ value of EPA-PC for $95 \mathrm{D}$ cells at $48 \mathrm{~h}$ was determined to be $15.97 \mu \mathrm{g} / \mathrm{ml}$. However, EPA-PE had no significant effect on the proliferation of 95D cells (Fig. 1d). In addition, neither EPA-PC nor EPA-PE affected LDH activity in the cell supernatant (Fig. 1e), indicating that they were not cytotoxic.

\section{Effect of EPA-PC and EPA-PE on the morphology of 95D cells}

To investigate the effect of EPA-PC and EPA-PE on the morphology of lung-cancer cells, morphological changes of the cells were observed using hematoxylin staining. As shown in Fig. 2, control group cells displayed normal morphology and adherence. Compared with the control group, many vacuoles appeared in the cells after the EPA-PC intervention and their number increased with increasing doses. After the EPA-PE intervention, a few vacuoles appeared in 95D cells. These results suggested that EPA-PC and EPA-PE could induce morphological changes and destroy the cell membranes of 95D cells.

\section{Effect of EPA-PC and EPA-PE on the apoptosis of 95D cells}

Cell apoptosis plays an important role in restraining tumor progression. To investigate the effect of EPA-PC and EPA$\mathrm{PE}$ on the apoptosis of 95D cells, acridine orange and ethidium bromide (AO/EB) staining was carried out. Fluorescence microscopy revealed that control cells appeared uniformly green, early apoptotic cells appeared pale orange, and late apoptotic cells appeared red. As shown in Fig. 3a, EPA-PC intervention significantly increased the number of early and late apoptosis cells, while EPA-PE only slightly promoted the apoptosis process of 95D cells at higher concentrations.

To further study morphological evidence of apoptosis in treated cells, TEM was performed to observe the submicroscopic structure of cells. As shown in Fig. 3b, chromatin was found to be evenly distributed in the nucleus of the cells constituting the control group. The mitochondria appeared full, the ridge structure was normal, and the bilayer membrane structure of the endoplasmic reticulum was found to be normal. In the EPA-PC group cells, euchromatin was concentrated, leading to a decrease in electron density in the nucleus and a small amount gathered around the nuclear
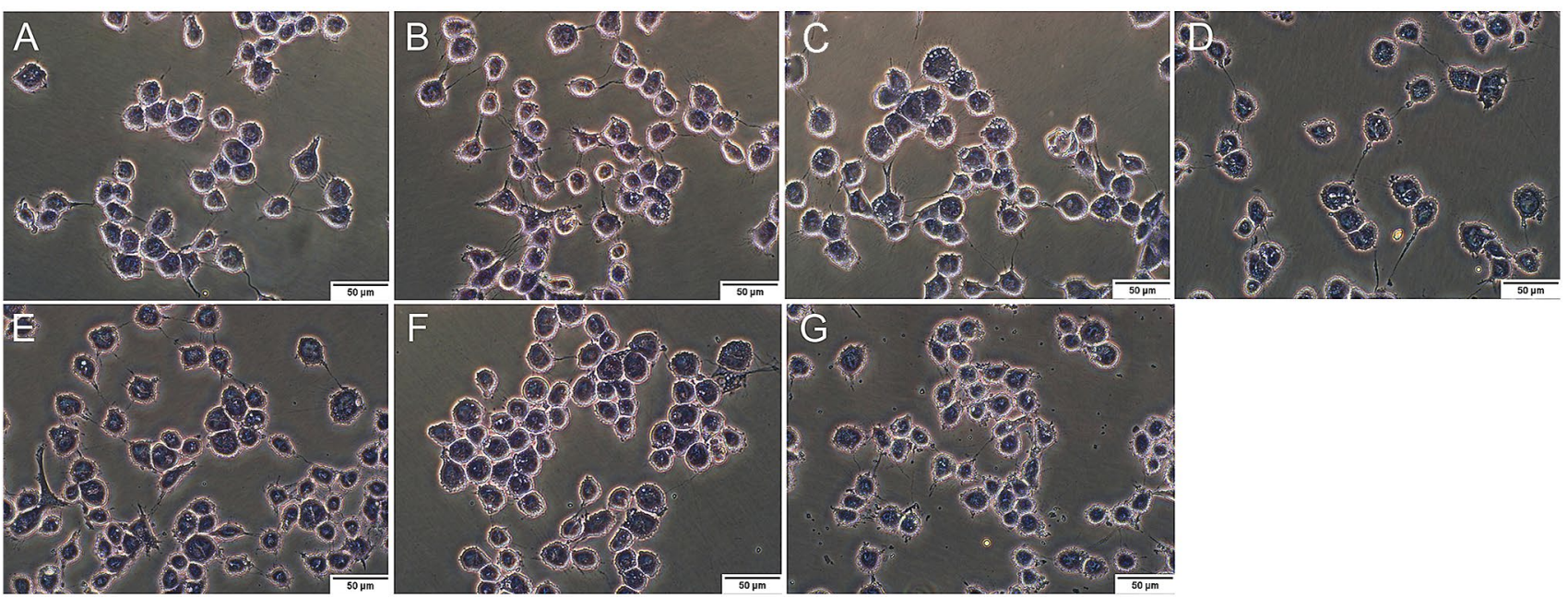

Fig. 2 Effect of EPA-PC and EPA-PE on morphology of 95D cells. 95D cells were treated with different concentrations of EPA-PC and EPA-PE for $24 \mathrm{~h}$. a $0 \mu \mathrm{g} / \mathrm{ml}$; b EPA-PC: $25 \mu \mathrm{g} / \mathrm{ml}$; c EPA-PC: $50 \mu \mathrm{g} /$

$\mathrm{ml}$; d EPA-PC: $100 \mu \mathrm{g} / \mathrm{ml}$; e EPA-PE: $25 \mu \mathrm{g} / \mathrm{ml}$; f EPA-PE: $50 \mu \mathrm{g} /$ $\mathrm{ml} ; \mathbf{g}$ EPA-PE: $100 \mu \mathrm{g} / \mathrm{ml}$. The morphology of the cells was observed under microscope (magnification $400 \times$ ) after hematoxylin staining 

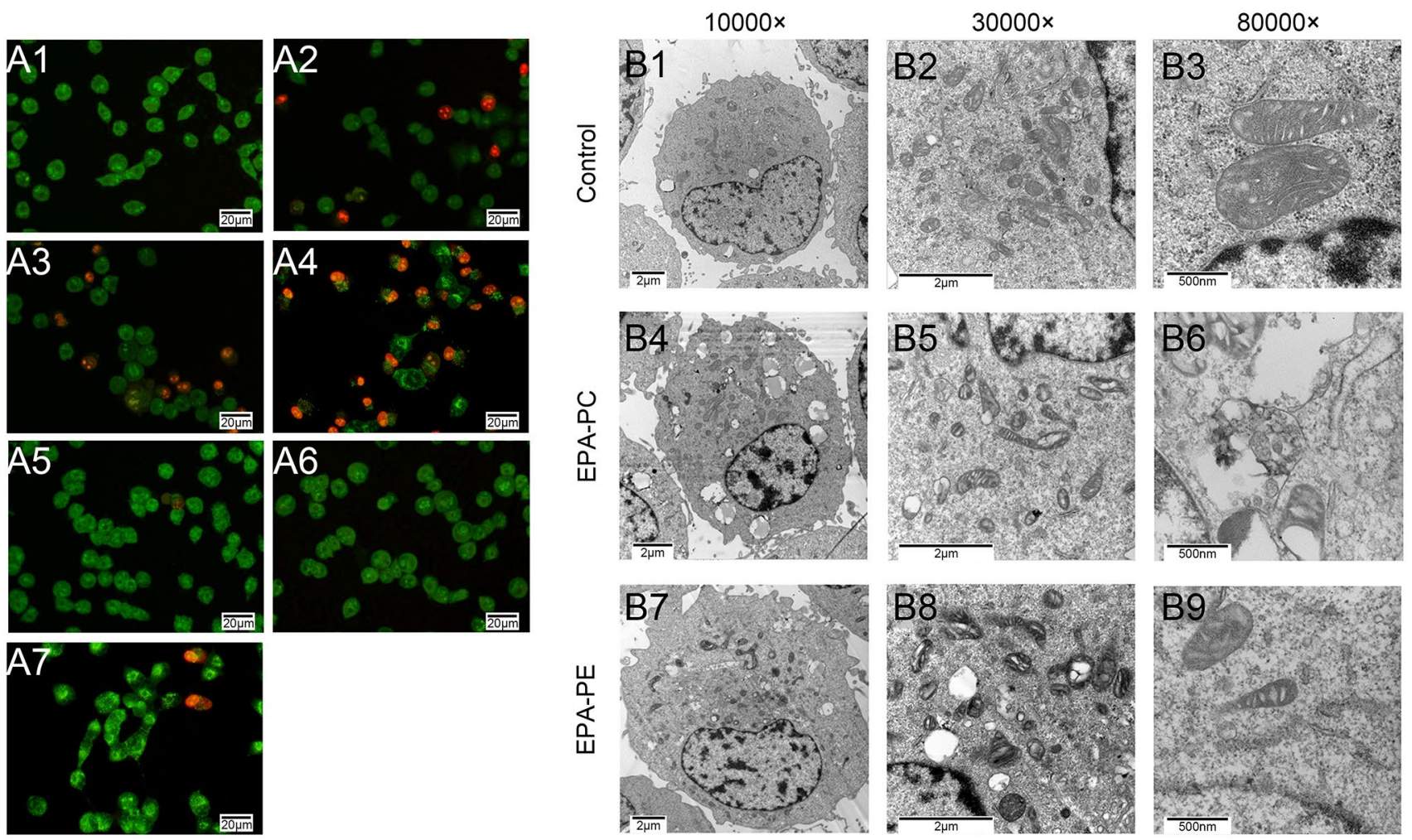

Fig. 3 Effect of EPA-PC and EPA-PE on apoptosis of 95D cells. a $\mathrm{AO} / \mathrm{EB}$ staining of 95Dcells after treated with different concentrations of EPA-PC or EPA-PE for $24 \mathrm{~h}$ (magnification $400 \times$ ). A1: $0 \mu \mathrm{g} / \mathrm{ml}$; A2: EPA-PC, $25 \mu \mathrm{g} / \mathrm{ml}$; A3: EPA-PC, $50 \mu \mathrm{g} / \mathrm{ml}$; A4: EPA-

membrane of the cell. The vacuolation in the cytoplasm was severe, and the endoplasmic reticulum and mitochondria exhibited different degrees of edema. In EPA-PE-treated cells, the mitochondrial structure changed significantly; the ridge structure showed severe edema and the lysosomes were destroyed.

\section{Effects of EPA-PC and EPA-PE on the expression of PPARY-related proteins}

Because EPA is an activator of PPAR $\gamma$, we determined the protein expression of PPAR $\gamma$. The results showed that EPA-PC and EPA-PE both upregulated PPAR $\gamma$ expression (Fig. 4a). Retinoid X receptor $\alpha(\mathrm{RXR} \alpha)$, which binds to PPAR $\gamma$ to form a heterodimer, was measured using western blot analysis. Compared to the control group, the protein expression of $\operatorname{RXR} \alpha$ was significantly upregulated. Phosphatase and tensin homolog deleted on chromosome 10 (PTEN) is the downstream target of PPAR $\gamma$ and also a key tumor suppressor (Teresi et al. 2008). Next, we determined the protein expression of PTEN. We found that the level of PTEN was significantly elevated after treatment with EPAPC and EPA-PE (Fig. 4b). These results suggested that
PC, $100 \mu \mathrm{g} / \mathrm{ml}$; A5: EPA-PE, $25 \mu \mathrm{g} / \mathrm{ml}$; A6: EPA-PE, $50 \mu \mathrm{g} / \mathrm{ml}$; A7: EPA-PE, $100 \mu \mathrm{g} / \mathrm{ml}$. b TEM was used to further study the apoptotic morphology of 95D cells (Column 1: magnification $10000 \times$. Column 2: magnification $30000 \times$. Column 3: magnification $80000 \times$ )

EPA-PC and EPA-PE might promote the apoptosis of 95D via a PPAR $\gamma$-related mechanism.

\section{Effects of EPA-PC and EPA-PE on the expression of the key protein in PI3K/AKT signaling pathway}

PI3K pathway is the target of PTEN and we measured the expression of PI3K/AKT pathway signaling. Results showed that EPA-PC and EPA-PE significantly downregulated the protein expression of PI3K and p-AKT (Fig. 5).

\section{Effects of EPA-PC and EPA-PE on the mitochondrial apoptotic signaling pathway}

Bax, a pro-apoptotic protein, and Bcl-xl, an anti-apoptotic protein, both belong to the Bcl-2 family. Our results showed an increased Bax expression and decreased Bcl-xl expression after EPA-PC and EPA-PE intervention (Fig. 6a). Responding to damage and stimulation, Bax re-localizes on the mitochondrial membranes and inhibits the function of anti-apoptotic protein, Bcl-xl (Liu et al. 2014). To investigate whether EPA-PC and EPA-PE regulated the mitochondrial apoptotic pathway, we detected the levels of cyt-c in 

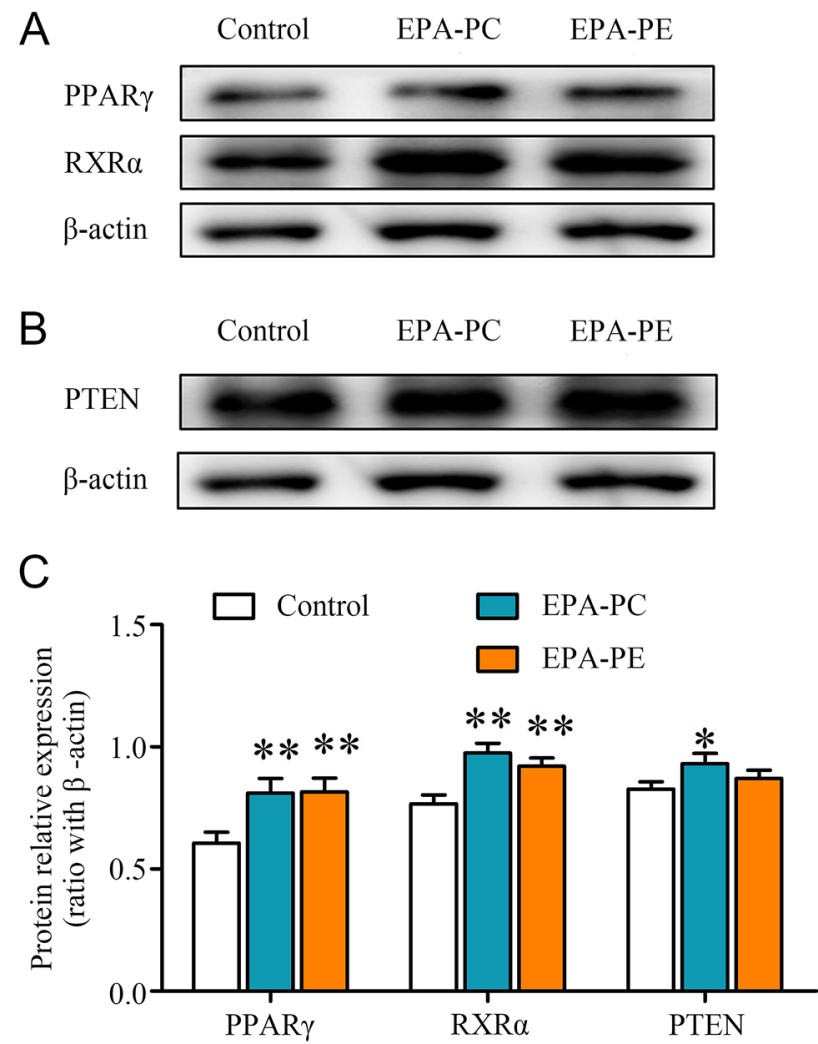

Fig. 4 Effects of EPA-PC and EPA-PE on the expression of PPAR $\gamma$ related proteins in 95D cells. a The protein expression of PPAR $\gamma$ and RXR $\alpha$. b The protein expression of PTEN. c Quantification of proteins in $\mathrm{A}, \mathrm{B}$. $\beta$-actin was used as an internal reference. ${ }^{*} P<0.05$; $* * P<0.01$ versus control group. The data are presented as the mean \pm SD of three separate experiments

the cytosol. As shown in Fig. 6c, EPA-PC and EPA-PE significantly increased the expression of cyt-c. Furthermore, the level of cleaved caspase- 3 expression was elevated. These results suggested that EPA-PC and EPA-PE upregulated the mitochondrial signaling pathway and accelerated apoptosis in $95 \mathrm{D}$ cells.

\section{Discussion}

It is generally believed that the omega-3 polyunsaturated fatty acid, EPA, has multiple physiological functions including anti-tumor activity. Marine life is a major source of EPA. The body wall of the sea cucumber is rich in EPA, which is mostly bound to phospholipids. This special form confers several properties upon EPA. In this study, we compared the effects of two different EPA-binding forms, PC and $\mathrm{PE}$, on the proliferation and apoptosis of 95D lung-cancer cells in vitro, and attempted to elucidate their mechanism of action.
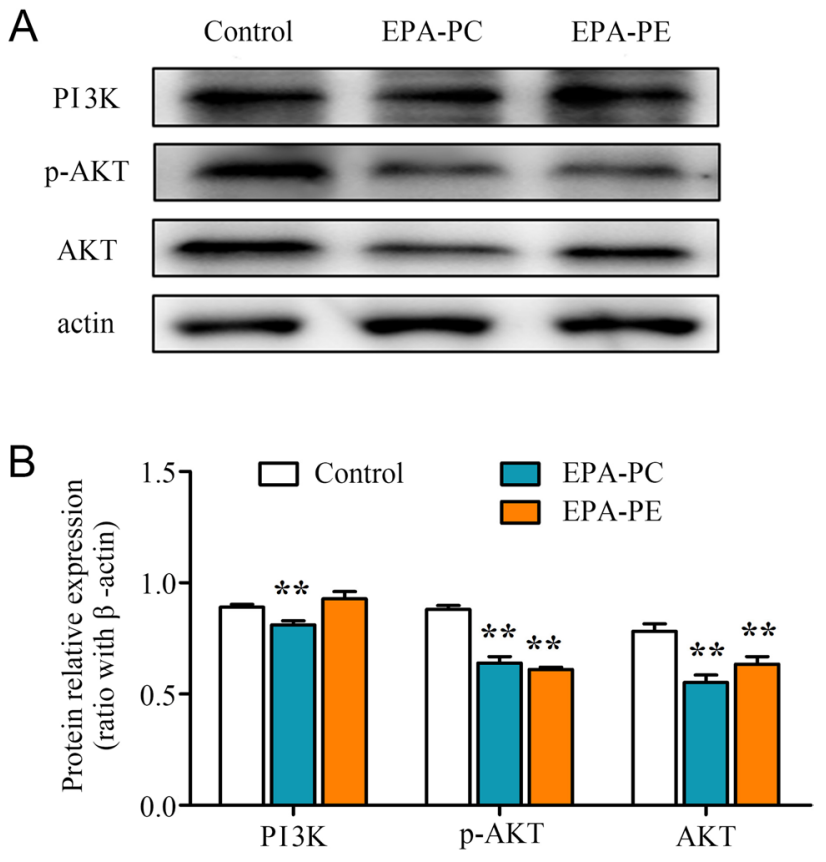

Fig. 5 Effects of EPA-PC and EPA-PE on the key protein expression levels of PI3K/AKT signaling pathway in $95 \mathrm{D}$ cells. a The protein expression of PI3K, p-AKT, and AKT. b Quantification of proteins in A. $\beta$-actin was used as an internal reference. ${ }^{*} P P<0.01$ versus control group. The data are presented as the mean \pm SD of three separate experiments

In vitro studies have shown that EPA can inhibit proliferation of various cancer cell lines, such as colon, breast, and human cervical carcinoma HeLa cells (Du et al. 2015; Hossain et al. 2009; Zheng et al. 2017). In our study, EPAPC significantly inhibited the proliferation of 95D cells; however, EPA-PE did not exhibit this effect. Apoptosis is an active and orderly self-destruction process regulated by genes under certain physiological and pathological conditions (Zhang et al. 2019). When apoptosis occurs, the cell morphology and intracellular structure change significantly. Shahid et al. (2017) reported that apoptosis is accompanied by a condensation of the nuclear chromatin, expansion of endoplasmic reticulum, vacuolization, and mitochondrial swelling. Similarly, our results showed that EPA-PC and EPA-PE induced significant structural changes in organelles, such as the ER and mitochondria, which manifested as lumen swelling and internal-folding disorders in 95D cells, indicating that EPA-PC and EPA-PE could promote apoptosis in these cells.

PPAR $\gamma$ is a ligand-dependent nuclear transcription factor (Mueller et al. 2000). When the ligand is activated, a heterodimer of PPAR $\gamma$ and RXR $\alpha$ is formed and modulates target gene expression at the transcriptional level to participate in the regulation of a series of metabolic pathways and physiological activities (Issemann et al. 1990). EPA and its derivatives, as natural PPAR $\gamma$ ligands, elicit good anticancer 
A

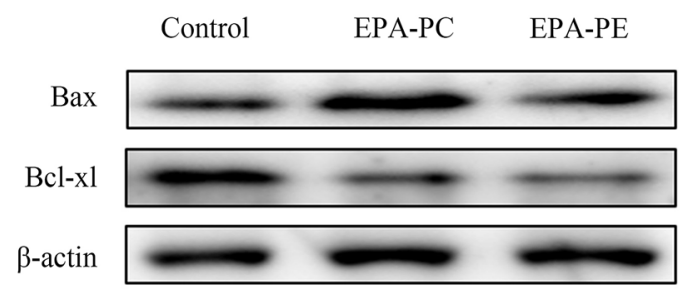

C

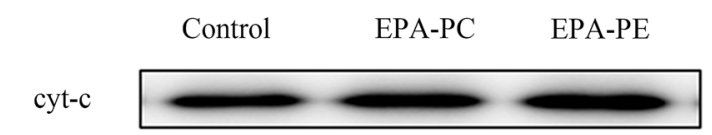

cleavedcaspase-3

caspase-3

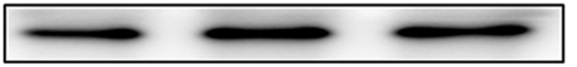

$\beta$-actin
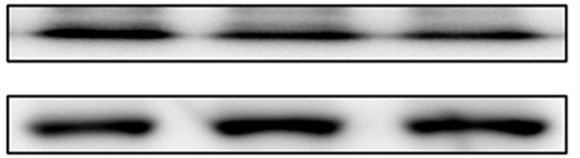

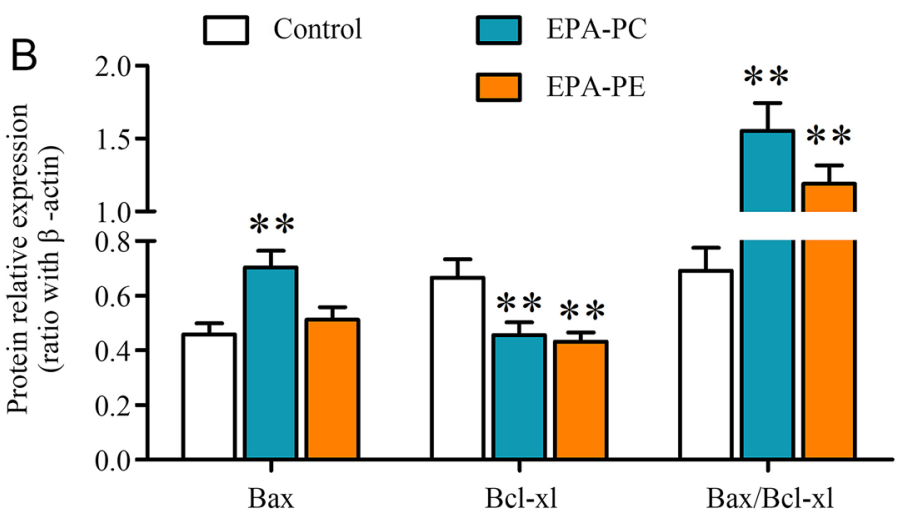

D

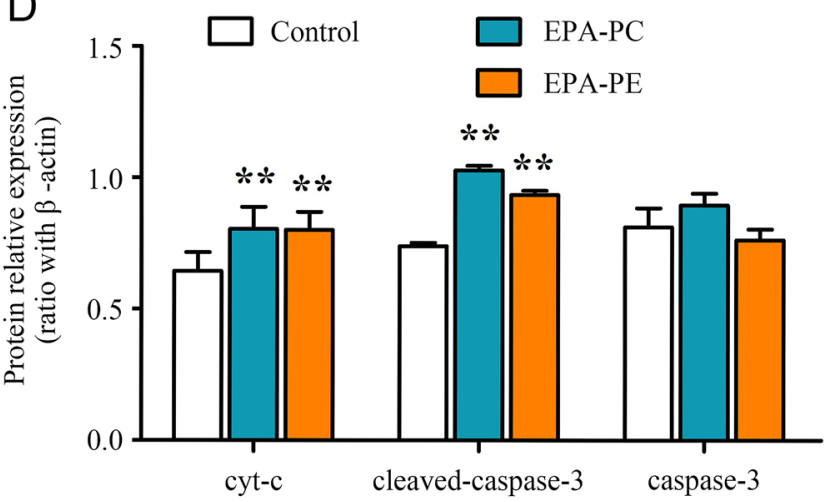

teins in (c). $\beta$-actin was used as an internal reference. $* * P<0.01$ versus control group. The data are presented as the mean \pm SD of three separate experiments

and block the PI3K/AKT transduction pathway to inhibit the growth of HCC cells and induce apoptosis. We obtained similar results and found that EPA-PC and EPA-PE elevated PTEN protein expression by activating PPAR $\gamma$ and repressed PI3K/AKT signaling.

A study by Zhang et al. (2013) reported apoptosis-related protein expression can be regulated by the PI3K/AKT pathway. These authors proved that baicalein could induce apoptosis in EC109 cells by downregulating the anti-apoptotic component, Bcl-2, and upregulating the pro-apoptotic component, Bax, by decreasing the PI3K/AKT signals. Results from our study were similar and indicated that EPA-PC and EPA-PE promoted the expression of Bax and inhibited Bcl$\mathrm{xl}$. Bax is a sensor for cell damage and stimulation. When apoptosis occurs, Bax inserts into the mitochondrial outer membrane and increases its permeability to induce mitochondrial apoptosis, while anti-apoptotic proteins like Bcl-2 and Bcl-xl play a role in preventing the formation of mitochondrial pores (Zhang et al. 2017; Zhou et al. 2018a, b). A key step of the mitochondrial apoptotic pathway is the release of pro-apoptotic proteins from mitochondria, such as cyt-c (AlBasher et al. 2019). Cyt-c is a protein that transmits 
electrons in the electron transport chain in the mitochondria. When released into the cytosol, cyt-c binds to apoptotic protease activating factor 1 (Apaf1) to initiate the activation of caspases (Liu et al. 2016). Caspase-3 is a key execution enzyme downstream of the apoptotic cascade and signaling pathway (Maher et al. 2019). Our study showed that EPA-PC and EPA-PE could promote cyt-c release from mitochondria and increase activated caspase- 3 protein expression in 95D cells, indicating that targeting the mitochondrial pathway was one of the mechanisms of apoptosis induced by EPA-phospholipid.

In this study, we demonstrated that EPA-PC significantly inhibited proliferation and promoted apoptosis in 95D lungcancer cells. Further study revealed that the effects involved the PPAR $\gamma$-dependent PTEN/PI3K/AKT signaling pathways and the mitochondrial apoptotic pathway. EPA-PE had no significant effect on cell proliferation and only slightly promoted apoptosis in 95D cells. The difference in effects between EPA-PC and EPA-PE may be due to the different types of phospholipids to which they are attached. The specific mechanism still needs to be further elucidated.

\section{Materials and methods}

\section{Extraction of EPA-phospholipids}

EPA-phospholipids were extracted from sea cucumber (Zhoushan Fisheries Co., Ltd, Zhoushan, China). The extraction was performed as described by Liu et al. (2017). The fatty acid composition was determined using an Agilent 7820 Gas Chromatograph with a flame-ionization detector. EPA-PC contained $33.20 \%$ EPA and $10.50 \%$ DHA. EPA-PE contained $28.62 \%$ EPA and $3.56 \%$ DHA.

\section{Liposome preparation}

All samples used in this study were administered liposomes, which were prepared according to the modified method of Hossain et al. (2006). Equal molar EPA-PC/EPA-PE and cholesterol were dissolved in eggplant bottles with a small amount of chloroform. Subsequently, the mixed system was evaporated into a uniform film by nitrogen blowing, and then, D-Hanks solution was added. After ultrasonic treatment, a milky water suspension formed. Liposomes were obtained by filtration with a $0.22 \mu \mathrm{m}$ microporous membrane.

\section{Cell culture}

95D cells were purchased from Shanghai Institutes for Biological Sciences (Shanghai, China) and cultured in RPMI 1640 medium (Biological Industries, Kibbutz Beit-Haemeck, Israel) with $10 \%(\mathrm{v} / \mathrm{v})$ fetal bovine serum (FBS; Biological Industries, Kibbutz Beit-Haemeck, Israel), at $37{ }^{\circ} \mathrm{C}$ in an incubator containing $5 \% \mathrm{CO}_{2}$.

\section{Cell viability assay}

95D cells $\left(2 \times 10^{3}\right.$ cells per well $)$ were seeded into 96-well plates and incubated overnight. Then, the cells of treatment groups were treated with medium-containing EPAPC $(5,25,50$ and $100 \mu \mathrm{g} / \mathrm{ml})$ or EPA-PE $(50,100,200$, and $400 \mu \mathrm{g} / \mathrm{ml}$ ), and the control group was cultured with normal medium without EPA-PC or EPA-PE. After incubation for $24 \mathrm{~h}, 36 \mathrm{~h}$, and $48 \mathrm{~h}$, respectively, the cells were incubated with thiazolyl blue tetrazolium bromide (MTT, sigma, St. Louis, MO, USA) solution $(0.5 \mathrm{mg} / \mathrm{ml})$ for $4 \mathrm{~h}$. Acidic isopropanol was added to fully dissolve formazan, and the absorbance of the solution was measured at the wavelength of $570 \mathrm{~nm}$. The survival curve was plotted and the concentration required to inhibit cell growth by $50 \%$ $\left(\mathrm{IC}_{50}\right)$ was calculated (Han et al. 2018).

\section{LDH activity determination}

The LDH content was determined using an LDH kit (Nanjing Jiancheng Bioengineering Institute, Nanjing, China) according to the manufacturer's instructions.

\section{Hematoxylin staining}

95D cells $\left(3 \times 10^{3}\right.$ cells per well) were seeded into 24 -well plates. The cells of treatment groups were incubated with EPA-PC $(25,50$ and $100 \mu \mathrm{g} / \mathrm{ml})$ or EPA-PE $(25,50$ and $100 \mu \mathrm{g} / \mathrm{ml}$ ) for $24 \mathrm{~h}$, while the cells of the control group were incubated in the medium. Cells were then fixed with 95\% alcohol for $20 \mathrm{~min}$ and stained with $0.5 \%(\mathrm{w} / \mathrm{v})$ hematoxylin staining solution (Sigma, St. Louis, MO, USA) for $5 \mathrm{~min}$. After washing thoroughly with running water, diluted hydrochloric acid was added for color separation. Subsequently, the cells were immersed in ammonia water for approximately 5 min until the cells turned blue. Ultimately, the stained cells were placed under a microscope (IX51, Olympus, Tokyo, Japan) for observation and photographing. 


\section{Acridine orange/ethidium bromide (AO/EB) double staining assay}

95D cells $\left(3 \times 10^{3}\right.$ cells per well $)$ were seeded into 24 -well plates and incubated overnight. The cells of the treatment group were treated with EPA-PC (50 and $100 \mu \mathrm{g} /$ $\mathrm{ml}$ ) or EPA-PE (50 and $100 \mu \mathrm{g} / \mathrm{ml})$ for $24 \mathrm{~h}$, respectively. The cells of the control group were treated with normal medium. The cells were stained with $10 \mu \mathrm{l} / \mathrm{ml}$ of AO $(100 \mu \mathrm{g} / \mathrm{ml})$ and $10 \mu \mathrm{l} / \mathrm{ml}$ of EB $(100 \mu \mathrm{g} / \mathrm{ml})$ for $30 \mathrm{~s}$. The unbound dye was washed with PBS buffer solution. The morphology of cells was identified under fluorescent microscopy (IX51, Olympus, Tokyo, Japan) (Ramalingam et al. 2017).

\section{Transmission electron microscopy}

95D cells were obtained after treatment with EPA-PC $(100 \mu \mathrm{g} / \mathrm{ml})$ or EPA-PE $(100 \mu \mathrm{g} / \mathrm{ml})$ for $24 \mathrm{~h}$. The cells of the control group were treated with normal medium and then fixed with $2.5 \%$ glutaraldehyde and dehydrated with ethanol, and cells were stained with uranyl acetate and lead citrate. The ultra-structure of cells was photographed with a JEM-1200EX transmission electron microscope (TEM) and analyzed (JEM-1200EX, Tokyo, Japan) (Shi et al. 2014).

\section{Western blot analysis}

95D cells $\left(1 \times 10^{6}\right.$ cells per well $)$ were seeded into 6-cell plates. The cell treatment group was treated with EPA-PC $(100 \mu \mathrm{g} / \mathrm{ml})$ or EPA-PE $(100 \mu \mathrm{g} / \mathrm{ml})$, while the control group was treated with normal medium. After incubation for $24 \mathrm{~h}$, the cells were lysed with RIPA buffer and the cell lysates were centrifuged at $5000 \mathrm{rpm}$ for $10 \mathrm{~min}$ (centrifugal speed for obtaining protein used to detect cytochrome c (cyt-c) was 13,000 rpm). The protein concentration was determined using a BCA kit (Solarbio, Beijing, China) and adjusted to be consistent. The protein samples were separated by sodium dodecyl sulfate-polyacrylamide gel electrophoresis (SDSPAGE) according to molecular weight differences, and then, the target protein was transferred from the gel to a polyvinylidene fluoride (PVDF; Millipore, Bedford, MA) membrane. Subsequently, the PVDF membrane was blocked with $5 \%$ bovine serum albumin at room temperature for $2.5 \mathrm{~h}$ and incubated with appropriate primary antibodies including PPAR $\gamma$, PTEN, PI3K, p-AKT, AKT, Bax, Bcl-xl, cyt-c, and caspase-3 (Cell Signaling Technologies, Danvers, MA, USA) at $4{ }^{\circ} \mathrm{C}$ overnight. After washing with $1 \times$ TBST, the membrane was incubated with HRP-conjugated secondary antibody (Proteintech, Rosemont, IL, USA) at room temperature for $2 \mathrm{~h}$. Eventually, the immune blots were visualized by an automatic chemiluminescence apparatus (Tanon 5200, Shanghai, China) and quantified by the ImageJ software (NIH, Bethesda, MD, USA) (Mao et al. 2019).

\section{Statistical analysis}

The results were statistically analyzed by SPSS version 22.0. One-way analysis of variance (ANOVA) was used to detect the differences among the three groups, and LSD pairwise comparison was carried out, with $P<0.05$ as the statistical difference.

Acknowledgements This work was supported by National Key Research and Development Program of China (2018YFC0311203).

Author contributions JFW and CHX designed the research; YG, QY, and JFW performed experiments; YG, QZ, YYT, and YYL analyzed the data and interpreted results of experiments; YG, QZ, and YZY prepared figures; YG and QZ wrote manuscript as co-first author; YG, QZ, JFW, and CHX edited and revised manuscript.

\section{Compliance with ethical standards}

Conflicts of interest The authors declare that they do not have any commercial or associative interest that represents a conflict of interest in connection with the work submitted.

Animal and human rights statement This article does not contain any studies with human participants or animals performed by the authors.

Open Access This article is licensed under a Creative Commons Attribution 4.0 International License, which permits use, sharing, adaptation, distribution and reproduction in any medium or format, as long as you give appropriate credit to the original author(s) and the source, provide a link to the Creative Commons licence, and indicate if changes were made. The images or other third party material in this article are included in the article's Creative Commons licence, unless indicated otherwise in a credit line to the material. If material is not included in the article's Creative Commons licence and your intended use is not permitted by statutory regulation or exceeds the permitted use, you will need to obtain permission directly from the copyright holder. To view a copy of this licence, visit http://creativecommons.org/licenses/by/4.0/.

\section{References}

Abdi J, Garssen J, Faber J, Redegeld FA (2014) Omega-3 fatty acids, EPA and DHA induce apoptosis and enhance drug sensitivity in multiple myeloma cells but not in normal peripheral mononuclear cells. J Nutr Biochem 25:1254-1262

Acharya P, Talahalli RR (2019) Aging and hyperglycemia intensify dyslipidemia-induced oxidative stress and inflammation in rats: assessment of restorative potentials of ala and EPA + DHA. Inflammation 42:946-952

AlBasher G, AlKahtane AA, Alarifi S, Ali D, Alessia MS, Almeer RS, Abdel-Daim MM, Al-Sultan NK, Al-Qahtani AA, Ali H, Alkahtani S (2019) Methotrexate-induced apoptosis in human 
ovarian adenocarcinoma SKOV-3 cells via ROS-mediated bax/ bcl-2-cyt-C release cascading. OncoTargets Ther 12:21-30

Apostoli AJ, Skelhorne-Gross GE, Rubino RE, Peterson NT, Lena MA, Schneider MM, SenGupta SK, Nicol CJ (2014) Loss of PPAR $\gamma$ expression in mammary secretory epithelial cells creates a probreast tumorigenic environment. Int J Cancer 134:1055-1066

Bonnet N, Ferrari SL (2011) Effects of long-term supplementation with omega- 3 fatty acids on longitudinal changes in bone mass and microstructure in mice. J Nutr Biochem 22:665-672

Cai JC, Li R, Xu XN, Zhang L, Lian R, Fang LS, Huang YB, Feng XM, Liu XM, Li X, Zhu X, Zhang H, Wu JH, Zeng MS, Song EW, He YK, Yin YX, Li J, Li MF (2018) CK1 $\alpha$ suppresses lung tumour growth by stabilizing PTEN and inducing autophagy. Nat Cell Biol 20:465-478

Cao LQ, Chen XL, Wang Q, Huang XH, Zhen MC, Zhang LJ, Li W, Bi J (2007) Upregulation of Pten involved in rosiglitazone-induced apoptosis in human hepatocellular carcinoma cells. Acta Pharmacol Sin 28:879-887

Du L, Yang YH, Wang YM, Xue CH, Kurihara H, Takahashi K (2015) Antitumour activity of EPA-enriched phospholipids liposomes against S180 ascitic tumour-bearing mice. J Funct Foods 19:970-982

Eltweri AM, Thomas AL, Metcalfe M, Calder PC, Dennison AR, Bowrey DJ (2016) Potential applications of fish oils rich in omega-3 polyunsaturated fatty acids in the management of gastrointestinal cancer. Clin Nutr 36:65-78

Han M, Gao H, Ju P, Gao MQ, Yuan YP, Chen XH, Liu KL, Han YT, Han ZW (2018) Hispidulin inhibits hepatocellular carcinoma growth and metastasis through AMPK and ERK signaling mediated activation of PPAR $\gamma$. Biomed Pharmacother 103:272-283

Hossain Z, Kurihara H, Hosokawa M, Takahashi K (2006) Docosahexaenoic acid and eicosapentaenoic acid-enriched phosphatidylcholine liposomes enhance the permeability, transportation and uptake of phospholipids in Caco- 2 cells. Mol Cell Biochem 285:155-163

Hossain Z, Hosokawa M, Takahashi K (2009) Growth inhibition and induction of apoptosis of colon cancer cell lines by applying marine phospholipid. Nutr Cancer 61:123-130

Issemann I, Green S (1990) Activation of a member of the steroid hormone receptor superfamily by peroxisome proliferators. Nature 347:645-650

Jiang F, Zhang ZQ, Zhang Y, Pan XH, Yu L, Liu S (2015) L-carnitine ameliorates cancer cachexia in mice partly via the carnitine palmitoyltransferase-associated PPAR- $\gamma$ signaling pathway. Oncol Res Treat 38:511-516

Lee YR, Pandolfi CM (2018) The functions and regulation of the PTEN tumour suppressor: new modes and prospects. Nat Rev Mol Cell Biol 19:547-562

Lee YR, Yu HN, Noh EM, Kim JS, Song EK, Han MK (2007) Peroxisome proliferator-activated receptor $\gamma$ and retinoic acid receptor synergistically up-regulate the tumor suppressor PTEN in human promyeloid leukemia cells. Int J Hematol 85:231-237

Lehrke M, Lazar MA (2005) The many faces of PPAR $\gamma$. Cell 123:993-999

Liu DL, Bu HQ, Jin HM, Zhao JF, Li Y, Huang H (2014) Enhancement of the effects of gemcitabine against pancreatic cancer by oridonin via the mitochondrial caspase-dependent signaling pathway. Mol Med Rep 10:3027-3034

Liu YQ, Zhang JW, Zuo CJ, Zhang Z, Ni DL, Zhang C, Wang J, Zhang $\mathrm{H}$, Yao ZW, Bu WB (2016) Upconversion nano-photosensitizer targeting into mitochondria for cancer apoptosis induction and cyt C fluorescence monitoring. Nano Res 9:3257-3266

Liu YJ, Shi D, Tian YY, Liu YT, Zhan QP, Xu J, Wang JF, Xue CH (2017) Eicosapentaenoic acid-enriched phosphatidylcholine attenuated hepatic steatosis through regulation of cholesterol metabolism in rats with nonalcoholic fatty liver disease. Lipids 52:119-257

Maher M, Kassab AE, Zaher AF, Mahmoud Z (2019) Novel pyrazolo[3,4-d] pyrimidines: design, synthesis, anticancer activity, dual EGFR/ErbB2 receptor tyrosine kinases inhibitory activity, effects on cell cycle profile and caspase-3-mediated apoptosis. J Enzyme Inhib Med Chem 34:532-546

Mao L, Wang ML, Li YY, Liu YX, Wang JF, Xue CH (2019) Eicosapentaenoic acid-containing phosphatidylcholine promotes osteogenesis:mechanism of up-regulating Runx2 and ERKmediated phosphorylation of PPAR $\gamma$ at serine 112. J Funct Food 52:73-80

Mueller E, Smith M, Sarraf P, Kroll T, Aiyer A, Kaufman DS, Oh W, Demetri G, Figg WD, Zhou XP, Eng C, Spiegelman BM, Kantoff PW (2000) Effects of ligand activation of peroxisome proliferatoractivated receptor gamma in human prostate cancer. Proc Natl Acad Sci USA 97:10990-10995

Nasim F, Sabath BF, Eapen GA (2018) Lung Cancer. Med Clin N Am 103:463-473

Ni J, Zhou LL, Ding L, Zhao X, Cao HX, Fan F, Li HZ, Lou R, Du YY, Dong SC, Liu SW, Wang Z, Ma R, Wu JZ, Feng JF (2017) PPAR $\gamma$ agonist efatutazone and gefitinib synergistically inhibit the proliferation of EGFR-TKI-resistant lung adenocarcinoma cells via the PPAR $\gamma /$ PTEN/Akt pathway. Exp Cell Res 361:246-256

Peng ZL, Zhang C, Yan L, Zhang YP, Yang ZY, Wang JJ, Song C (2020) EPA is more effective than DHA to improve depressionlike behavior, glia cell dysfunction and hippcampal apoptosis signaling in a chronic stress-induced rat model of depression. Int J Mol Sci 21:1769

Petpiroon N, Bhummaphan N, Tungsukruthai S, Pinkhien T, Maiuthed A, Sritularak B, Chanvorachote P (2019) Chrysotobibenzyl inhibition of lung cancer cell migration through Caveolin-1-dependent mediation of the integrin switch and the sensitization of lung cancer cells to cisplatin-mediated apoptosis. Phytomedicine 58:152888

Ramalingam V, Revathidevi S, Shanmuganayagam TS, Muthulakshmi L, Rajaram R (2017) Gold nanoparticle induces mitochondriamediated apoptosis and cell cycle arrest in nonsmall cell lung cancer cells. Gold Bull 50:177-189

Rovito D, Giordano C, Plastina P, Barone I, Amicis FD, Mauro L, Rizza P, Lanzino M, Catalano S, Bonofiglio D, Andò S (2015) Omega-3 DHA- and EPA-dopamine conjugates induce PPAR $\gamma$ dependent breast cancer cell death through autophagy and apoptosis. Biochim Biophys Acta Gen Subj 1850:2185-2195

Sascha S (2015) Ligands for the nuclear peroxisome proliferator-activated receptor gamma. Trends Pharmacol Sci 36:688-704

Shahid M, Wang JF, Gu XL, Chen W, Ali T, Gao J, Han DD, Yang R, Fanning S, Han B (2017) Prototheca zopfii induced ultrastructural features associated with apoptosis in bovine mammary epithelial cells. Front Cell Infect Microbiol 7:299

Shen LH, Yi SZ, Huang LY, Li SG, Bai F, Lei SJ, Breitzig M, Czachor A, Sun HX, Zheng Q, Wang F (2019) MiR-330-3p promotes lung cancer cells invasion, migration, and metastasis by directly targeting hSOD2b. Biotechnol Appl Biochem 66:21-32

Shi JM, Huang HJ, Qiu SX, Feng SX, Li XE (2014) Griffipavixanthone from garcinia oblongifolia champ induces cell apoptosis in human non-small-cell lung cancer H520 cells in vitro. Molecules 19:1422-1431

Skelhorne-Gross G, Nicol GJ (2012) The key to unlocking the chemotherapeutic potential of PPAR $\gamma$ ligands: having the right combination. PPAR Res 12:1-13

Soni N, Ross AB, Scheers N, Nookaew I, Gabrielsson BG, Sandberg AS (2019) The omega-3 fatty acids EPA and DHA, as a part of a murine high-fat diet, reduced lipid accumulation in brown and white adipose tissues. Int J Bio Sci 50:5895 
Teresi RE, Waite KA (2008) PPAR $\gamma$, PTEN, and the fight against cancer. PPAR Res 8:932632

Yang R, Cai TT, Wu XJ, Liu YN, He J, Zhang XS, Ma G, Li J (2018) Tumor YAP1 and PTEN expression correlates with tumor-associated myeloid suppressor cell expansion and reduced survival in colorectal cancer. Immunology 155:263-272

Zhang W, Wu N, Li ZX, Wang LY, Jin JW, Zha XL (2006) PPAR activator rosiglitazone inhibits cell migration via upregulation of PTEN in human hepatocarcinoma cell line BEL-7404. Cancer Biol Ther 5:1008-1014

Zhang WK, Long YP, Zhang JH, Wang CY (2007) Modulatory effects of EPA and DHA on proliferation and apoptosis of pancreatic cancer cells. J Huazhong Univ Sci Tech-Med 27:547-555

Zhang HB, Lu P, Guo QY, Zhang ZH, Meng XY (2013) Baicalein induces apoptosis in esophageal squamous cell carcinoma cells through modulation of the PI3K/Akt pathway. Oncol Lett 5:722-728

Zhang J, Li L, Peng YT, Chen Y, Lv XY, Li S, Qin X, Yang H, Wu CH, Liu YY (2017) Surface chemistry induces mitochondria-mediated apoptosis of breast cancer cells via PTEN/PI3K/AKT signaling pathway. Biochim Biophys Acta Mol Cell Res 1865:172

Zhang TT, Xu J, Wang YM, Xue CH (2019) Health benefts of dietary marine DHA/EPA-enriched glycerophospholipids. Prog Lipid Res 75:100997
Zheng WL, Wang XD, Cao WJ, Yang BW, Mu Y, Dong YS, Xiu ZL (2017) E-configuration structures of EPA and DHA derived from, Euphausia superba, and their significant inhibitive effects on growth of human cancer cell lines, in vitro. Prostaglandins Leukot Essent Fatty Acids 117:47-53

Zhou LJ, Mo YB, Bu X, Wang JJ, Bai J, Zhang JW, Cheng AB, Ma JH, Wang YW, Xie YX (2018a) Erinacine facilitates the opening of the mitochondrial permeability transition pore through the inhibition of the PI3K/Akt/GSK-3 $\beta$ signaling pathway in human hepatocellular carcinoma. Cell Physiol Biochem 50:851-867

Zhou MM, Che HX, Huang JQ, Zhang TT, Xu J, Xue CH, Wang YM (2018b) Comparative study of different polar groups of EPA-enriched phospholipids on ameliorating memory loss and cognitive deficiency in aged SAMP8 mice. Mol Nutr Food Res 62:1700637

Zhu HZ, Liu QY, Tang JW, Xie Y, Xu XL, Huang RY, Zhang YGY, Jin KP, Sun BC (2017) Alpha1-ACT functions as a tumour suppressor in hepatocellular carcinoma by inhibiting the PI3K/AKT/mTOR signalling pathway. Cell Physiol Biochem 41:2289-2306 